\title{
Assesment of the treatment of earlobe keloids with triamcinolone injections, surgical resection, and local pressure
}

\section{Avaliação do tratamento de queloide do lóbulo da orelha com infiltração de triancinolona, retirada cirúrgica e compressão da cicatriz}

\author{
Silvia Mandello Carvalhaes ${ }^{1}$; Andy Petroianu, TCBC-MG²; Mauro Augusto Tostes Ferreira3; Virgínea Magalhães de Barros ${ }^{4}$;
} RAQUel VIRGÍNEA LOPES ${ }^{4}$

\begin{abstract}
A B S S T R A C T
Objective: To evaluate the combined treatment of ear lobe keloids. Methods: We studied 46 consecutive patients with 81 ear lobe keloids. Patients underwent local infiltration of triamcinolone acetonide (TCN) at concentrations of $40 \mathrm{mg} / \mathrm{ml}$ (Group 1), $20 \mathrm{mg} / \mathrm{ml}$ (Group 2) and $10 \mathrm{mg} / \mathrm{ml}$ (Group 3). The volume of TCN infiltrate varied according to the size of the lesion. Treatment consisted of three monthly injections before surgery, excision of keloid in the fourth month and perioperative infiltration, followed by two more leaks TCN within two months. Patients used earrings pressure on the scar after operation for four months. The pressure exerted by earrings in the ear lobe was measured electronically. Post-treatment follow-up of patients was 24 months. Results: TCN at concentrations of $20 \mathrm{mg} / \mathrm{ml}$ and $40 \mathrm{mg} / \mathrm{ml}$ were effective for the treatment of keloids, no difference between the groups $(p=0.58)$. However, patients in which TCN was infiltrated the $10 \mathrm{mg} / \mathrm{ml}$ had poor involution of keloid and the study of this group was stopped. Conclusion: the combination of infiltration TCN month to 20 mg/ $\mathrm{mL}\left(1.2 \mathrm{mg}\right.$ to $2.0 \mathrm{mg}$ per $\mathrm{mm}^{3} \mathrm{TCN}$ injury), surgical excision and pressure application device is effective for treatment of keloid ear lobe.
\end{abstract}

Key words: Keloid. Triamcinolone Acetonide. Wound Healing. Surgical Procedures, Operative.

\section{INTRODUCTION}

$\mathrm{T}^{\mathrm{n}}$ he a wound repair process covers a wide spectrum of results, from the absence of healing to exuberant scarring. The mechanism of regulation of anomalous healing is not known; nor is the part or parts of the process in which lies the disorder that keeps the scar on inflammatory and proliferative phase. Keloids are scars that respond in an exaggerated way to a skin lesion, pushing the boundaries of the original wound and invading the normal skin, appearing about three months after trauma, and not regressing spontaneously, being a characteristic of humans. The main complaints are pain, itching of uncertain etiology and great aesthetic discomfort. The incidence of keloids in people with black skin ranges from $4.5 \%$ to $16 \%$, approximately 15 times more than in whites. Its incidence is higher in between ten and 30 years of age ${ }^{1}$, with no preference between genders.

Keloids are multifactorial, relating with physical, chemical, biological and endogenous agents. There seems to be a genetic predisposition, with exacerbated immune response related to emotional factors. Fibroblasts derived from keloids have an increased expression of the $p^{2} 3^{2}$ gene, with increased response to the organic stimuli involved in wound healing. The beta transforming growth factor (TGF$\beta 1)$ is also high in keloids ${ }^{3}$.

Corticosteroid therapy is considered the best treatment for keloids ${ }^{1.4}$. Triamcinolone (TCN) in keloids has been used since 1965 due to its efficacy ${ }^{6}$. The mechanism by which intradermal TCN actson the injury is not fully elucidated. Its greatest effect is in the inflammatory and proliferativephase, interfering in local erythema and edema resulting from capillary dilation. There is evidence of its effect on the phagocytic activity of macrophages and modulation of the fibroblasts function in collagen synthesis.

The therapeutic objective depends on the patient'ssymptoms and aesthetic complaints caused by the keloid. Although the literature on the subject is wide, there is still no effectiveness-established treatment for keloid cure. This paper presents the authors' experience evaluating the combined approach consisted of application of TCN, surgical resection, and compression to treat earlobe keloids.

1. Plastic Surgery Clinic, Hospital Governador Israel Pinheiro-IPSEMG, Minas Gerais State, Brazil, Brazil; 2. Department of Surgery, Faculty of Medicine, Universidade Federal de Minas Gerais, Minas Gerais State, Brazil; 3. Department of Anatomy and Imaging, Faculty of Medicine, UFMG, Minas Gerais State, Brazil; 4. Hospital UNIMED, Hospital SEMPER, Belo Horizonte, Minas Gerais State, Brazil. 


\section{METHODS}

We studied 46 patients with 81 keloids, primary and recurrent, located in the earlobe. All keloids were caused by piercing injury for earring placement (Figure 1). Patients aged under 14 years and those with skin infections were not included.

This prospective study was approved by the Ethics Committee and Research, Department of Surgery, Faculty of Medicine and the Ethics Committee on Human Research (COEP) of UFMG, under number 133/07.

To determine the optimal dose of TCN in the treatment of keloids, the patients were divided into three groups to receive different drug concentrations: Group 1 $(40 \mathrm{mg} / \mathrm{ml})$, consisting of 20 patients with 33 keloids; Group $2(20 \mathrm{mg} / \mathrm{mL})$, consisting of 16 patients with28 keloids; and Group $3(10 \mathrm{mg} / \mathrm{ml})$, formed by 10 patients with 20 keloids. The amount of TCN injected into the base of the lesion is proportional to the volume of the keloid. We injected $0.05 \mathrm{ml}$ to $0.1 \mathrm{ml} \mathrm{TCN}$ per $\mathrm{mm} \square$ of keloid monthly for three months (Figure 2).

We recorded volumes of keloids $(\mathrm{V})$ in cubic millimeters $(\mathrm{mm} \square)$ in the preoperative phase with a digital caliper. The diameter and height of the lesions (D) were measured, and the volumetric calculation resulted from the following equation: average of diameter and height cubed, multiplied by the value of pi (3.14) and divided by six.

In the fourth month, the patients underwent excision of the keloid followed by TCN injection into the open area of the wound edges, using the same volume injected earlier. The wound was sutured with monofilament 5-0 nylon. All procedures were performed under local anesthesia with lidocaine injected into the keloid. After the suture, a pressureearring was applied (Figure 3A), coated with allergenic cotton knit on the scar (Figure 3B), and kept for four months, 18 hours a day.

The pressure exerted by the earrings, of $30 \mathrm{mmHg}$, was measured in the Technological Centre Foundation - Physical Tests Sector, at the Universidade Federal de Minas Gerais, through the universal electromechanical testing machine.

To verify the effectiveness of the treatment, patients were followed for at least one year after the last dose of corticosteroids (Figure 4). To assess the best dose of TCN to be injected, we considered as therapeutic success no recurrence of the injury after removal and infiltration of corticosteroids. We compared the number of relapses in all three groups. We considered relapse when there was scar growth beyond the limits of the wound at the end of treatment, combined with complaints of itching and pain.

Two variables were considered together, as each indicates failure in the treatment of keloids. The statistical analysis took into account the patient's symptoms (pain and itching), and changes in the morphological characteristics of the lesion, such as stiffness and volume change, and the second variable took into account

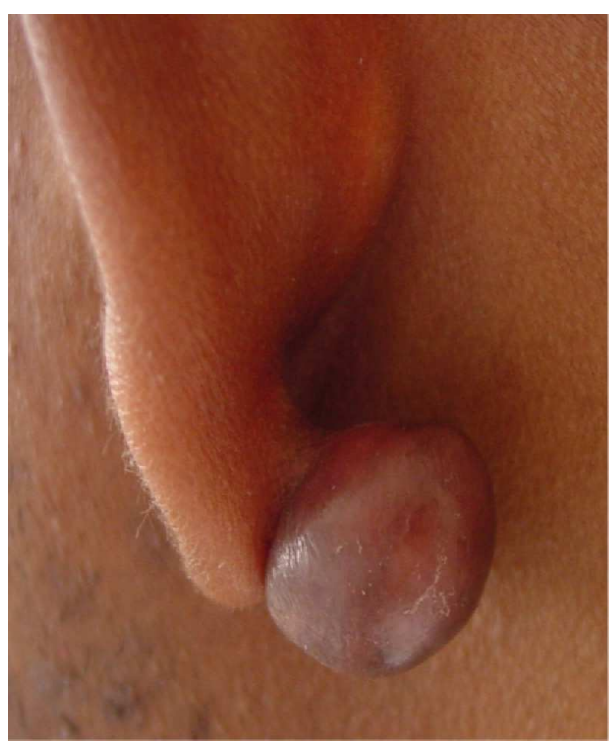

Figure 1 - Earlobe keloid before treatment.

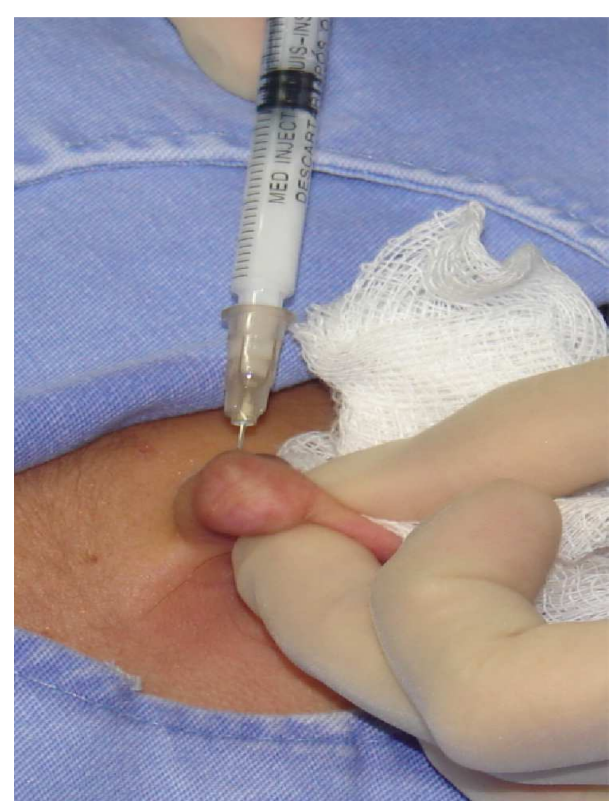

Figure 2 - Perioperative infiltration followed by injury excision.

recurrence. We used the chi-square test with Fisher correctionfor statistical analysis.

\section{RESULTS}

In Group 1 (TCN to $40 \mathrm{mg} / \mathrm{ml}$ ) two of the 20 subjects (10\%) experienced an anaphylactic reaction after the second infiltration. There was general malaise, lip swelling, flushing, dry cough, abdominal pain, symptoms that improved after intravenous administration of $1000 \mathrm{ml}$ 

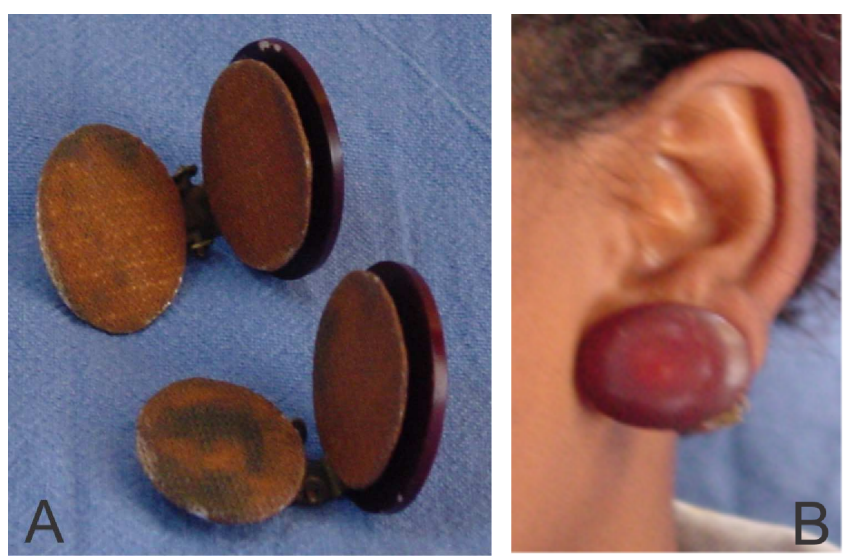

Figure 3 - Pressure earrings. A) Detail; B) on the spot, coated with hypoallergenic material, cotton knit.

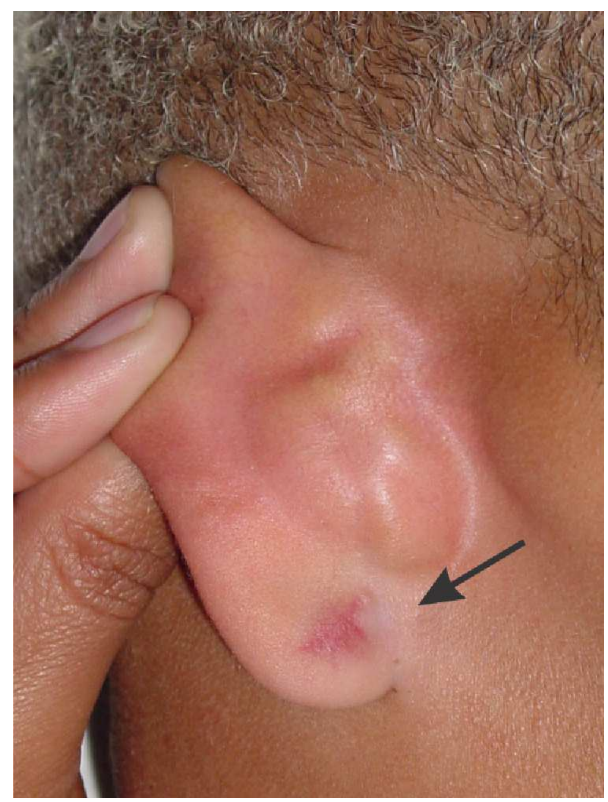

Figure 4 - $\quad$ Aspect of the earlobe after treatment.

of physiological saline. Only in this group there was a whitish deposit of TCN at the time of resection of the keloid, but with no clinical significance. There were two keloid recurrences in less than one year (6\%).

In Group 2 (TCN 20 mg / ml), one patient (6.2\%) had anaphylactic reactions to TCN after the third infiltration. There was wound infection in one patient, treated with cephalexin for ten days without modification of the therapeutic result, considered optimal. There was one recurrence of keloid in less than one year (4.5\%).

In Group 3 (TCN to $10 \mathrm{mg} / \mathrm{ml}$ ), three patients maintained itching complaint until the third dose and showed no injury improvement. In two other patients, there was lesion growth. These adverse events occurred in $50 \%$ of patients, rendering unacceptable the continuation of this TCN dose. Treatment was discontinued and all patients in this group resumed treatment as set for Group 2. These patients were not relocated in Group 2. Thus, the group 3 was not part of the final analysis and statistical work.

There was no difference in the evolution of the symptoms and scar appearance between the groups that received $20 \mathrm{mg} / \mathrm{ml}$ and $40 \mathrm{mg} / \mathrm{ml}$. After the third infiltration, all patients were asymptomatic and their injuries did not progress. There was improvement in scar stiffness and size regression. There was no difference $(p=0.58)$ between the results obtained with patients undergoing infiltration of $40 \mathrm{mg} / \mathrm{ml}$ and $20 \mathrm{mg} / \mathrm{mlTCN}$.

\section{DISCUSSION}

Even a thorough review of the literature does not allow precise analysis of the results proclaimed. Some causes of this difficulty are: lack of homogeneity description and characterization of anomalous scars; statistical methodology used; limited number of patients; insufficient follow-up; and different criteria used to define relapse.

Treatment of keloids is based on three types of potential medical intervention, and they act in the complex cascade of events leading to wound healing: manipulation of the intrinsic properties of wound synthesis process; correction of the balance between normal physiological and abnormal collagen synthesis, and in its regulatory humoral factors; modification of various immune and inflammatory responses that occur during the healing process. Therapeutic modalities include, in most cases: compression of the keloid, cryosurgery, application of silicone plates, operative excision followed or not by radiotherapy, isolated radiotherapy, laser application, and intralesional injection of corticosteroids.

Keloidcompression is based on collagenfragmentation and fibroblast degradation, the minimum effective pressure for this purpose being greater than $24 \mathrm{mmHg}$, so as to exceed the capillary pressure ${ }^{7}$. We present a device developed by us, which was applied to the ear lobe, but of difficult usage in other parts of the body. Cryotherapy lends itself to treat minor injuries in leucodermas, by leading to keloid cold ischemia and possible volumetric reduction of the lesion ${ }^{8}$. This limitation has been overcome in part by applying plates of soft silicone, which improve the hydration of the lesion, eventual improvement in the color of the lesion and surrounding skin, and increased tolerance to keloidcompression? ${ }^{9}$. Radiotherapy is used usually after surgical excision. The keloid is the benign lesion most often treated by radiotherapy ${ }^{10}$, which was first used in 1906. The betatherapy is the most frequently used ionizing radiation mode ${ }^{11}$. However, it is known for its carcinogenic potential, contraindication in children, and it's side effects on scars and keloids, such as atrophy, hypopigmentation, and skin necrosis. The LASER (Light Amplification by Stimulated Emission of Radiation), has shown good results in the treatment of keloids. It acts by modulating the anomalous tissue growth, but the results 
depend on the type of laser, exposure time and location of the keloid ${ }^{12}$. The isolated surgical removal entails risk of recurrence, ranging from $45 \%$ to $100 \%$ of the cases, and should never be used in monotherapy ${ }^{13}$.

Among the intralesional corticosteroids, the preferred drug is triamcinolone (TCN). Although there are studies on general aspects and treatment of keloids, the best concentration and TCN dose for treatment has not yet been determined. The concentrations proposals in the literature range from $10 \mathrm{mg} / \mathrm{ml}$ to $40 \mathrm{mg} / \mathrm{ml}$ and the total dose, up to $120 \mathrm{mg}^{5}$. TCN is the only drug approved for keloid treatment by the Food and Drug Administration (FDA), USA. It's topical use, however, is ineffective to treat keloids.

The infiltration of TCN at the base of keloid is intended to act in the place of the mediators of the healing process and of the fibroblasts with greater replicative capacity. The retention of the drug in small volumes in the scar site reduces its systemic effects. In this study, the total dose infiltrated in keloids was lower than that found in the literature, and yet, therapeutic success was obtained in almost all patients.

Anaphylactic reactions using TCN are well documented. Corticosteroids are paradoxically responsible for anaphylactic type 1 reactions, mediated by lgE antibodies.
The allergens may be the steroids themselves or the liquid used in the solution, usually carboxymethylcellulose ${ }^{14}$ and succinate ${ }^{15}$

Compression of the keloid is an already establishedmethod to improve the quality of the scar ${ }^{8}$. Nevertheless, there is no publication on the pressure intensity that must be performed in the scar. In this study, we used the higher pressure bearable in all patients, without discomfort.

The development of stem cell research ${ }^{16}$ has helped to elucidate the balance of formation and cellular remodeling activity. It is described that flags (cytokines), molecular alterations in receptor cytoplasmic membrane of fibroblasts and genetic mutations alter the healing process ${ }^{17}$. Growth factors are important in the modulation of various cellular activities ${ }^{18}$. New therapeutic strategies to enhance wound healing and promote the formation of healthy scars are currently being studied, using anti-TGF-â antibodies.

TCN infiltration at a concentration of $20 \mathrm{mg} / \mathrm{ml}$ in combination with the scar removal and compression earring is effective and sufficient to treat earlobe keloids. The administration of lower doses of corticosteroids is insufficient, and higher doses are unnecessary to obtain good therapeutic results.

\title{
R E S U M O
}

\begin{abstract}
Objetivo: avaliar o tratamento combinado do queloide do lóbulo da orelha. Métodos: Foram estudados 46 pacientes consecutivos com 81 queloides de lóbulo da orelha. Os pacientes submeteram-se a infiltração local de triancinolona acetonida (TCN) nas concentrações de 40mg/ml (Grupo 1), 20mg/ml (Grupo 2) e 10mg/ml (Grupo 3). O volume de TCN infiltrado variou de acordo com o tamanho da lesão. O tratamento consistiu em três infiltrações mensais no pré-operatório, exérese do queloide no quarto mês e infiltração peroperatória, seguida de mais duas infiltrações de TCN nos dois meses seguintes. Os pacientes usaram brincos de pressão sobre a cicatriz após a operação durante quatro meses. A pressão exercida pelos brincos no lóbulo da orelha foi aferida eletronicamente. O seguimento pós-tratamento dos pacientes foi 24 meses. Resultados: A TCN nas concentrações de 20mg/m/ e 40mg/ml foram eficazes para o tratamento do queloide, sem diferença entre si $(p=0,58)$. No entanto, os pacientes nos quais a TCN foi infiltrada a $10 \mathrm{mg} / \mathrm{ml}$ não tiveram involução satisfatória do queloide e o estudo desse grupo foi interrompido. Conclusão: $A$ combinação de infiltração mensal de TCN a $20 \mathrm{mg} / \mathrm{ml}\left(1,2 \mathrm{mg}\right.$ a 2,0mg de TCN por $\mathrm{mm}^{3}$ de lesão), exérese cirúrgica e aplicação de dispositivo de pressão é eficaz para tratamento do queloide de lóbulo da orelha.
\end{abstract}

Descritores: Queloide. Triancinolona Acetonida. Cicatrização. Operação Cirúrgica.

\section{REFERENCES}

1. Urioste SS, Arndt KA, Dover JS. Keloidalscars and hypertrophic scars: review and treatment strategies. SeminCutan Med Surg.1999;18(2):159-71.

2. De Felice B, Ciarmiello LF, Mondola P, Damiano S, Seru R, Argenziano $C$, et al. Differential p63 and p53 expression in human keloid fibroblast and hypertrophic scar fibroblasts. DNA Cell Biol.2007;26(8):541-7.

3. Bettinger DA, Yager DR, Diegelmann RF, Cohen IK. The effect of TGF-beta on keloid fibroblast proliferation and collagen synthesis. PlastReconstr Surg. 1996;98(5):827-33.
4. Ketchum LD, Robinson DW, Masters FW. Follow-up on treatment of hypertrophic scars and keloids with triamcinolone. PlastReconstr Surg. 1971;48(3):256-9.

5. Griffith BH, Monroe CW, McKinney P.A follow-up study on the treatment of keloids with triamcinolone acetonide. PlastReconstr Surg. 1970;46(2):145-50.

6. Babin RW, Ceilley RI. The freeze-injection method of hypertrophic scar and keloid reduction. Otolaryngol Head Neck Surg. 1979;87(6):911-4.

7. Sawada $Y$, Sone K.Hydration and occlusion treatment for hypertrophic scars and keloids. Br J Plast Surg.1992;45(8):599603. 
8. Shepherd JP, DawberRP.The response of keloid scars to cryosurgery. Plastic Reconstr Surg.1982;70(6):677-82.

9. Linares HA, LarsonDL, Willis-Galstaun BA. Historical notes on the use of pressure in the treatment of hypertrophic scars or keloids. Burns.1993:19(1):17-21.

10. Botwood N, Lewanski C, LowdellC. The risks of treating keloids with radiotherapy. $\mathrm{Br} J$ Radiol.1990;72(864):1222-4.

11. DarziMA,Chowdri NA, Kaul SK, Khan M. Evolution of various methods of treating keloids and hypertrophic scars: a 10-year follow-up study. Br J Plast Surg.1992;45(5):374-9.

12. Abergel RP, Meeker CA, Oikarinen H, Oikarinen Al, Uitto J. Retinoid modulation of connective tissue metabolism in keloid fibroblast cultures. Arch Dermatol.1985;121(5):632-5.

13. Shaffer JJ, TaylorSC, Cook-Bolden F. Keloidal scars: a review with a critical look at therapeutic options. J Am AcadDermatol.2002;46(2 Suppl Understanding):S63-97.

14. Cosman B, Wolff M. Correlation of keloid recurrence with completeness of local excision. A negative report. PlastReconstr Surg.1972;50(2):163-6.
15. Patterson DL, Yunginger JW, Dunn WF, Jones RT, Hunt LW Anaphylaxis induced by carboxymethylcellulose component of injectable triamcinolone. Ann Allergy Asthma Immunol.1995;74(2):163-6.

16. TuanTL, NichterLS. The molecular basis of keloid and hypertrophic scar formation. Mol Med Today.1998;4(1):19-24.

17. Kim WJ. Cellular signaling in tissue regeneration. Yonsei Med J. 2000;41(6):692-703.

18. Lee TY, Chin GS, Kim WJ, Chau D, Gittes GK, Longaker MT. Expression of transforming growth factor beta 1, 2, and 3 proteins in keloids. Ann Plast Surg. 1999;43(2):179-84.

Received 02/02/2014

Accepted for publication 18/04/2014

Conflict of interest: None

Source of funding: no

Address for correspondence:

Mauro Augusto Tostes Ferreira

E-mail: matferreira2@hotmail.com 